\title{
MEDIA IN THE PREVISIT STAGE OF THE TOURIST EXPERIENCE: PORT CAMPBELL NATIONAL PARK
}

\author{
BRENT D. MOYLE and W. GLEN CROY \\ Tourism Research Unit, Monash University, Narre Warren, VIC, Australia
}

\begin{abstract}
In the past 50 years there has been an enormous expansion in the number and types of protectedarea users. This has increased physical pressures on protected areas, and created perceptual impacts for visitors. Importantly, the role of the media in promoting and providing expectations can also be used as a tool to manage potential impacts. Within this context, research was undertaken at Port Campbell National Park (PCNP), Victoria, Australia. Implementing this study not only created awareness of the varied information sources visitor decisions were based on, but also provided valuable insights into the role of the media in the management of expectations. Results indicated that users obtain information from four sources, creating a complex user image and management scenario. An analysis of visitor expectations of the facilities and services at PCNP indicated that induced image sources created inflated expectations of functional attributes. Practical implications are provided for protected area management agencies on the importance of using the media as a tool in the previsit experience, to enhance overall satisfaction. Importantly, creating presite images of functional attributes of parks, in induced information sources, may have important positive implications for overall user satisfaction.
\end{abstract}

Key words: Media; Image; Expectations; Satisfaction; Protected areas

\section{Introduction}

Natural areas around the world have been used as sites of recreation, leisure, and tourism for centuries (Butler \& Boyd, 2000). In the past 50 years, however, there has been an enormous expansion in the numbers and types of users (Pigram \& Jenkins, 1999). This growth in visitor usage can largely be attributed to natural and protected areas' important role in tourism promotional imagery. Increasingly, this image is coming from the media (Smith \&
Croy, 2005). Coupled with increased accessibility to natural and protected areas, this rise in visitor popularity has amplified physical and perceptual impacts in these inherently fragile areas (Booth \& Cullen, 1995). These impacts are predominately occurring, not surprisingly, in front-country areas, and are having enormous effects on the visitor experience (Vaske, Donnelly, \& Whittaker, 2000). Consequently, parks are being faced with increased visitor management issues. As a result, protected area agencies are turning to the media as a tool 
in the previsit stage of the visitor experience to proactively manage both the physical impacts on the park and the perceptual impacts on the visitor.

In tourism, the role of image has been emphasized as an important component of the visitor experience, especially for shaping visitors' perceptions and expectations of a destination (MacKay \& Fesenmaier, 2000; Mannell \& Iso-Aloha, 1987). Though the significance of image in the creation of visitor expectations in the previsit experience has been asserted, little study has been undertaken in Australia as related to images of natural and protected areas (the exceptions are Burns \& Howard, 2003; Frawley 1989; Watkinson, 2002). The shaping of expectations also makes image a basis for visitor participation, motivation, and more significantly as a primary decision-making factor (Baloglu \& McCleary 1999; Walmsley \& Young 1998). The media plays a large role in the formation of place images, and with the pervasiveness of the media, also creates familiarity (Croy \& Wheeler, 2007). As such, the media has been highlighted as an important dimension of visitor satisfaction management (Hwang, Lee, \& Chen, 2005; Neal, Sirgy, \& Uysal, 1999).

Visitor expectation and satisfaction studies in protected areas generally only include media that can be directly controlled by protected area management agencies (Coffey, 2001). Nonetheless, the term media within the broader tourism literature and especially destination-image studies includes all sources of travelers' information (Beerli \& Martin, 2004; Gursoy \& McCleary, 2004). Following from these image studies, the term media in this research includes any source visitors use to obtain information on a destination, including television, books, friends and relatives, radio, brochures, tourism information centers, roadmaps, travel guides, signage, and the Internet. By using this broader definition of media there will be a greater appreciation of possible avenues to understanding and managing visitor expectations during the previsit stage of a recreation experience.

This article focuses on visitor satisfaction through the development and achievement of expectations. In particular, it researches the role of the media in the creation and management of visitor expectations of Port Campbell National Park, in Victoria, Australia. Within this context, this ar- ticle presents an extended consideration of the previsit stage of management, and especially in the context of the visitor experience (anticipation and travel-to phase) portrays the potential influence of the media for on-site satisfaction.

\section{Media in the Previsit Experience}

The visitor experience and resultant satisfaction is influenced not just on-site but over all five phases of the experience: (1) anticipation, (2) travelto, (3) on-site, (4) travel-back, and (5) recollection (Hammitt, 1980). Although studies have stressed the importance of managing the holistic visitor experience to produce the most satisfying experience possible for visitors (Pizam \& Milman, 1993; Sternberg, 1997; Vitterso, Virkinn, Vistad, \& Vaagland, 2000), the anticipation and recollection phases have been largely omitted from protected-area studies on satisfaction. Instead, natural and protected-area satisfaction research has focused on the on-site phase of the experience (Akama \& Kieti, 2003; Buultjens, Ratnayake, Gnanapala, \& Aslam, 2004; Kerviliet \& Nowell, 2000; Lange, 1990; Mugica \& De Lucio, 1996; Ostrowski, 1984). The media, in its role in the creation of previsit expectations through image, plays an important role in visitors' overall satisfaction with an experience.

Images are generally formed through organic, induced, and real agents (Jenkins, 1999). Organic agents are those from general life experiences, induced agents are those supplied by the destination marketer, and real agents are drawn from the actual destination experience. Within these agents, from the user's perspective, real agents are the most credible followed by organic; induced agents are identified as the least credible. All the same, studies are generally confined to viewing image formation as starting once a decision has been made to travel to a destination. Alternatively, Croy and Wheeler (2007) suggest that image formation is an engaging and extended process, much more extended than is often portrayed or considered. The temporal nature of image formation goes back as far as a user can remember, and quite potentially a bit further. The spatial nature of image formation is increasingly global the more we are exposed to multiple locations, especially through the media. Nonetheless, it has been found that the 
organic agents are more motivating, building emotive associations with the place, whereas the induced agents are used more for functional perceptions of a location (Croy \& Wheeler, 2007). Therefore, whereas the marketed images may not influence motivations for destination selection, they will have a much greater role in developing place-specific expectations, including experiences, behaviors, and facilities of a destination. Table 1 displays the image formation agents, and illustrates the role of each group in the different phases within the presite stage of the visitor experience.

By using information sources, this article focuses on the role of the media in the previsit stage of the visitor experience. This involves using the media active during place specific information sourcing and the travel-to phase (displayed in Table 1), to understand the media's role in providing visitors with accurate expectations of the facilities at the setting.

\section{Method}

This article uses Port Campbell National Park (PCNP) as the location to discuss the role of the media in the previsit stage of an experience in pro- tected areas. PCNP stretches along the tourist route, Great Ocean Road, Victoria, Australia (Fig. 1 ), and is an iconic natural tourist attraction in itself (Tourism Australia, 2006). The park attracts over 3 million international and domestic visitors annually, especially to the Twelve Apostles and Loch Ard Gorge (Fig. 2). Images of the Twelve Apostles are used frequently in tourism promotional media, and are particularly featured in travel shows. PCNP was chosen by the park management agency due to interest in the complexities of visitor satisfaction since the development of the often-critiqued Twelve Apostles Visitor Centre (Munro, King, \& Polonosky, 2006).

A survey was administered at PCNP over a 3week period in June 2005 (winter off-season). This survey was structured to collect information at each of the five phases of a recreation experience, although obviously only providing indicative responses for the recollection phase. Previsit information sources of respondents' awareness and specific knowledge of the PCNP were obtained. There was a prompted list of responses, derived from previous studies and information from the park's management agency with space for addi-

Table 1

Image Formation Agents' Fit with the Previsit Experience

\begin{tabular}{|c|c|c|}
\hline Tourists' Information Sources & $\begin{array}{l}\text { Potential Provision } \\
\text { Information }\end{array}$ & Information Agent \\
\hline General information (Not sourcing/searching) & $\begin{array}{l}\text { - Autonomous } \\
\text { - Covert Induced } \mathrm{II}^{2} \\
\text { - Unsolicited organic } \\
\text { - Solicited organic }\end{array}$ & $\begin{array}{l}\text { - General media } \\
\text { - "Unbiased" media reports } \\
\text { - Friends and relatives } \\
\text { - Friends and relatives }\end{array}$ \\
\hline $\begin{array}{l}\text { Awareness Motivations } \\
\text { General information sourcing }\end{array}$ & $\begin{array}{l}\text { - Overt Induced II } \\
\text { - Covert Induced I } \\
\text { - Covert Induced II } \\
\text { - Unsolicited organic } \\
\text { - Solicited organic }\end{array}$ & $\begin{array}{l}\text { - Tour operators/information centers, } \\
\text { general tourism Web sites } \\
\text { - Celebrity endorsements } \\
\text { - "Unbiased" media reports } \\
\text { - Friends and relatives } \\
\text { - Friends and relatives }\end{array}$ \\
\hline $\begin{array}{l}\text { Availability } \\
\text { Place-specific information sourcing }\end{array}$ & $\begin{array}{l}\text { - Overt Induced I } \\
\text { - Overt Induced II } \\
\text { - Solicited organic }\end{array}$ & $\begin{array}{l}\text { - Advertising } \\
\text { - Tour operators/information centers, } \\
\text { general tourism Web sites } \\
\text { - Friends and relatives }\end{array}$ \\
\hline $\begin{array}{l}\text { Expectations EvaluationChoice } \\
\text { Travel to }\end{array}$ & $\begin{array}{l}\text { - Overt Induced I } \\
\text { - Overt Induced II } \\
\text { - } \text { Organic }^{8}\end{array}$ & $\begin{array}{l}\text { - Advertising } \\
\text { - Tour operators/information centers } \\
\text { - On-site }\end{array}$ \\
\hline
\end{tabular}

Source: Adapted from Gartner (1993). 


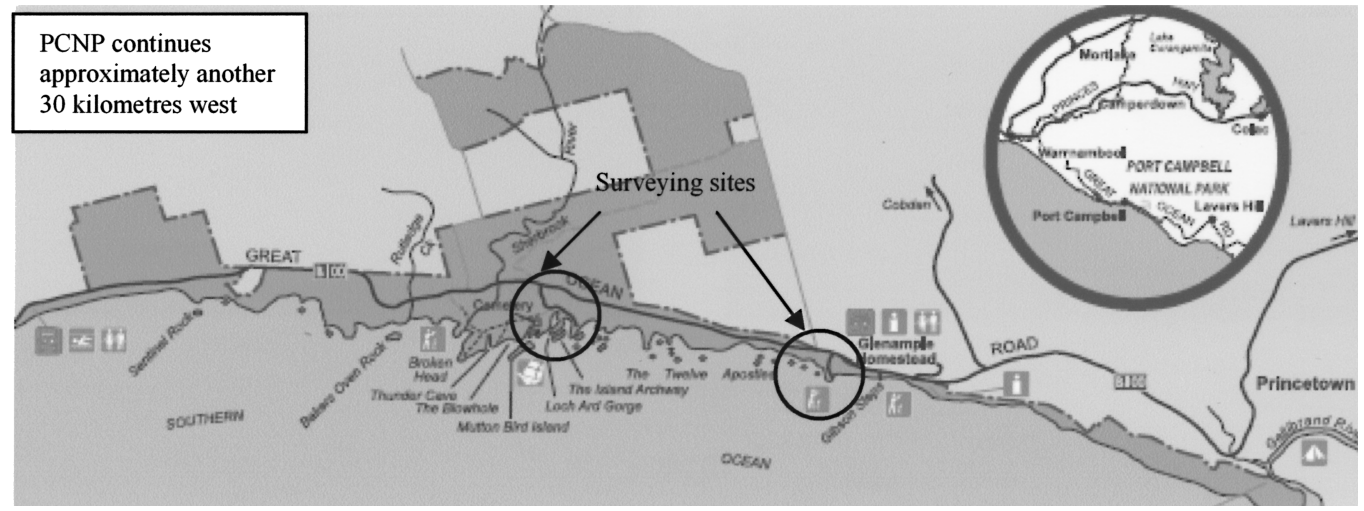

Figure 1. Surveying sites at Port Campbell National Park, Victoria, Australia. [Source: Parks Victoria (1998).]

tional sources. In addition, visitors' expectations of on-site facilities were examined using prompted scale responses. For the facility questions, the scaled list was largely derived from the park management agency's Summer Satisfaction Survey. This list was repeated later in the survey to measure respondents' satisfaction with their actual experience. The potential that visitors' actual experience would influence recalled expectations was largely limited through the temporal separation of questions in the survey.

Using a convenience sampling method, respondents were intercepted at the exit points to the two main attractions, the Twelve Apostles and Lord Ard Gorge. Visitors to these two sites ranged from single travelers to tour busloads. Even for the tour buses, no more than two people were selected

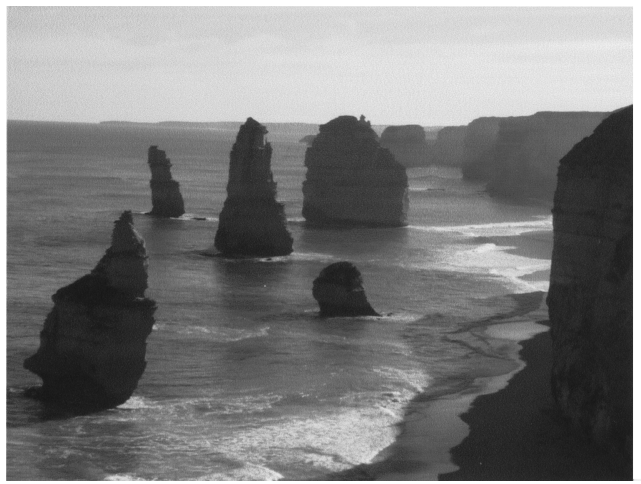

from any travel group. Respondents were encouraged to complete the survey on-site with a table, chair, and some light refreshments. However, prepaid envelopes were supplied to respondents bound by time constraints. A total of 205 surveys were distributed at PCNP, 141 of these surveys were completed on-site, with 64 visitors selecting the mail-back option. Of the 64 that selected the mail-back option, 41 were returned. This achieved 182 completed surveys. During data entry, four incomplete surveys were eliminated, leaving 178 valid and useable surveys ( $87 \%$ response rate).

\section{Results}

The following analysis displays the results from the survey at PCNP. A sociodemographic

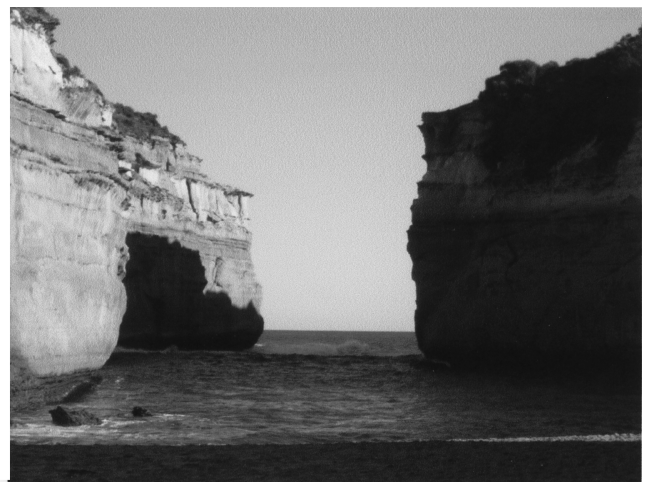

Figure 2. The Twelve Apostles (left) and Loch Ard Gorge (right). 
profile of respondents is discussed first. This is followed by a table and description of the information sources used by visitors to form the previsit image and expectations of PCNP. Additionally, these information sources are further separated into the different stages of the previsit experience to illustrate the complexity of image formation in this case. Furthermore, this analysis evaluates if these information sources provided realistic expectations of the setting at PCNP.

Traditionally, protected-area visitors have been identified as predominantly male and highly educated, yet this has changed with the global expansion of tourism, and protected-area visitors are now growing in both number and diversity (Kearsley \& Croy, 2001). Reflecting this emerging trend in previous research, PCNP also attracts a diverse user base. The sociodemographic profile revealed that a visitor to PCNP would most probably be younger, from an urban area, hold a higher educational qualification, be part of a couple, and currently work in a full-time higher-level occupation. Table 2 presents the sources of media used by re-

\section{Table 2}

Information Sources of Visitors to PCNP

\begin{tabular}{lrc}
\hline Information Sources & Count & $\begin{array}{c}\text { Percentage } \\
\text { of Cases }\end{array}$ \\
\hline Friends/relatives & 84 & 47.2 \\
Tourist information center & 59 & 33.1 \\
Local knowledge, live nearby & 53 & 29.8 \\
Television & 43 & 24.2 \\
Travel agent & 42 & 23.6 \\
RACV & 35 & 19.7 \\
Magazines & 34 & 19.1 \\
Internet site & 33 & 18.5 \\
Signage on roads & 31 & 17.4 \\
Parks Victoria brochure & 31 & 17.4 \\
Television commercials & 30 & 16.9 \\
Melways/roadmap & 25 & 14.0 \\
Major news article & 25 & 14.0 \\
Port Campbell Parks note & 19 & 10.7 \\
Accommodation & 19 & 10.7 \\
Local council/community/library & 18 & 10.1 \\
Radio & 18 & 10.1 \\
Local news article & 18 & 10.1 \\
Seeing park from road while passing & 15 & 8.4 \\
Cinema commercial & 13 & 7.3 \\
Book & 12 & 6.7 \\
Other & 48 & 27.2 \\
Total & 703 & $394.9 \%$ \\
\hline
\end{tabular}

${ }^{\text {a }}$ Totals more than 100 due to multiple responses. spondents at PCNP. This list includes both organic and induced sources.

The 178 respondents used 703 information sources, meaning an average of four pieces of media were used by each respondent. This highlights the diversity of sources and the potential complexity of images that shape the expectations of visitors to PCNP. Table 2 shows that just under half (47\%) of the respondents obtained information on PCNP from the past experiences of family and friends. Tourism-specific media such as visitor information centers, travel agents, and the Internet were also popular. Locals were frequent visitors to PCNP, although many visitors that considered themselves locals actually lived up to $150 \mathrm{~km}$. away from the park. This also reflects the scale of Australia, especially outside the major urban areas. Table 2 emphasizes the broad selection of media that contributes to the formation of complex images and resultant expectations tourists have of a destination before visitation. In the case of PCNP, Table 2 demonstrates the vast range of sources that need to be managed to ensure visitors' expectations are realistic, and the inherent complexity of managing the holistic experience.

To compare this information to the discussion above, and especially to Table 1, the information sources were allocated to Gartner's (1993) imageformation agents. These allocated media sources were then assigned to the particular phases of the visitors' previsit experience (Table 3). Table 3 indicates the role and level of influence of each media source in shaping visitors' expectations at PCNP. Particularly important in the context of this article are the role and level of influence the induced sources have in creating expectations of the setting.

As identified in Table 2 friends and relatives play a large role in the provision of information about PCNP. First, it is important to mention that Table 3 shows the solicited and unsolicited agents combined, which may slightly overemphasize the role of friends and family in the specific previsit phases. This is due to the inability to interpret whether the information about PCNP was solicited by the respondents or not. If the information was not solicited from friends and relatives, it would indicate that this source would only inform the general information stage and not inform the func- 
Table 3

Information Sources and Experience Stage

\begin{tabular}{|c|c|c|}
\hline Tourists' Information Sources & Information Agent & Count \\
\hline \multirow[t]{14}{*}{ Place-specific information sourcing } & Friends/relatives & 84 \\
\hline & Tourist information center & 59 \\
\hline & Travel agent & 42 \\
\hline & Internet site & 33 \\
\hline & Parks Victoria brochure & 31 \\
\hline & Television commercials & 30 \\
\hline & Melways/roadmap & 25 \\
\hline & Port Campbell Parks Note & 19 \\
\hline & Accommodation & 19 \\
\hline & Local council/community/library & 18 \\
\hline & Local news article & 18 \\
\hline & Movie commercial & 13 \\
\hline & Other brochure & 10 \\
\hline & & $\overline{401}$ \\
\hline \multicolumn{3}{|l|}{ Expectations, Evaluation, Choice } \\
\hline \multirow[t]{10}{*}{ Travel to } & Tourist information center & 59 \\
\hline & Travel agent & 42 \\
\hline & Signage on roads & 31 \\
\hline & Melways/roadmap & 25 \\
\hline & Port Campbell Parks Note & 19 \\
\hline & Local council/community/library & 18 \\
\hline & Local news article & 18 \\
\hline & Seeing park from road while passing & 15 \\
\hline & Other brochure & 10 \\
\hline & & $\overline{237}$ \\
\hline \multicolumn{3}{|l|}{ Expectations } \\
\hline On-site/Previous experience & Local knowledge, live near by & 53 \\
\hline
\end{tabular}

tional expectations of the setting (specific facilities). However, it is assumed that a portion of the friends and relatives information was solicited and provided expectations of the setting.

Table 3 indicates that the main information sources for the place-specific phase are friends and relatives, tourist information centers, travel agents, and Web sites. When traveling to PCNP, the most used information sources were again tourist information centers and travel agents, although now coupled with signs and maps. This indicates that, whereas the image, and particularly the motivating image to visit the area, is from a wide and diverse range of sources, the functional image of PCNP is actually from a limited (particularly geographically) range of sources. This also indicates that these functional sources that have a greater opportunity to be managed by the park's management agency.

As mentioned earlier, the organic flow of the recreation experience makes the management of visitors' expectations central to overall satisfac- tion. Consequently, expectation and experience measures were taken from respondents to identify if the above-noted media sources created realistic expectations of the functional attributes of PCNP. Respondents were first asked to rate their expectations of 14 functional or setting-specific attributes using a 6-point Likert-type scale $(6=$ Very strongly agree, $5=$ Strongly agree, $4=$ Agree, $3=$ Slightly agree, $2=$ Neither agree or disagree, $1=$ Disagree). Later, respondents were asked to rate their experiential satisfaction with the same attributes on a similar 6-point Likert-type scale. By comparing respondents' expectations of these functional attributes with their satisfaction it can be determined if the media sources created realistic expectations of the setting.

The mean responses from these 14 attributes and two sets of questions were then compared using a paired-samples $t$-test (Pallant, 2005). In this case, a paired-samples $t$-test is comparing respondents' expectations with their satisfaction to identify areas where there is a satisfaction gap. Table 
4 presents the results of the paired-samples $t$-tests and indicates if the sources of media used by visitors created realistic expectations of the setting at PCNP. Additionally, the mean difference was tested at the $0.05 \%$ significance level. The significance measure infers the differences between expectations and satisfaction was unlikely to occur by chance in the wider population. All the same, the significance measure does not indicate the magnitude of the effect between the two temporal measures. The eta squared value (or the effect-size statistic) was also calculated to determine the magnitude of the difference between expectations and satisfaction for this particular sample. According to Cohen (1969), 0.01 is a small effect, 0.06 is a moderate effect, and 0.14 and above is a large effect. The effect-size statistic will indicate if the sources of media provided a small to large difference in expectations compared to the actual experience for visitors at PCNP.

As Table 4 portrays, all attributes had a difference in means, and all were positive values. This indicates that the sample's experience of all functional attributes measured did not meet expectations. Especially evident in Table 4 is the large gap between expectations and satisfaction with signage and information on natural, historical, and cultural features, where the mean difference was over 0.8 . To identify if inferences could be applied to the population of visitors to PCNP, the difference in means was tested at the 0.05 percent level.
This identified that there was a statistically significant difference between visitors' expectations and their satisfaction with 10 out of the 14 functional attributes. These results make inferences to the wider population of visitors to PCNP, indicating that the difference obtained between visitors' expectations and satisfaction was unlikely to occur by chance. Also identified from this test was the relatively small difference in means for safe and secure car parking, previsit information, accessible shelter, and a safe and secure environment within PCNP, which consequently could not be reliably inferred for the wider population of park users.

The major result, after identifying difference in means, and the potential inferences made to the population was the magnitude or effect size between the means. Using Cohen's (1969) framework, in this sample, there was a large effect size between respondents' expectations and satisfaction with information on the natural, cultural, and historical features, signage, access to facilities and infrastructure, and the level of traffic and crowding at sites. This large effect size indicates that there was a large difference between the expected functional attributes and the actual experience in the case of PCNP. With the role of place-specific information in creating functional expectations, it is indicated that the induced media used by visitors to PCNP has contributed to creating these unmet expectations. There was a moderate effect size between respondents' expectations and satisfac-

Table 4

Expectations and Experience-Paired Samples $t$-test and Eta ${ }^{2}$ Value

\begin{tabular}{|c|c|c|c|c|c|c|}
\hline Expectations vs. Satisfaction & $\begin{array}{l}\text { Mean } \\
\text { Diff }\end{array}$ & $S D$ & $t$ & $d f$ & $\begin{array}{c}\text { Sig. } \\
\text { 2-tailed }\end{array}$ & $\mathrm{Eta}^{2}$ \\
\hline Information on natural, historical, and cultural features & 0.809 & 1.421 & 7.594 & 177 & 0.000 & 0.2457 \\
\hline Signage clear and helpful & 0.860 & 1.569 & 7.311 & 177 & 0.000 & 0.2319 \\
\hline Accessibility to facilities, infrastructure safe, secure, and & 0.725 & 1.468 & 6.586 & 177 & 0.000 & 0.1968 \\
\hline Traffic/crowding at sites kept to a minimum & 0.860 & 1.768 & 6.485 & 177 & 0.000 & 0.1920 \\
\hline Tracks and paths well maintained & 0.551 & 1.540 & 4.768 & 177 & 0.000 & 0.1138 \\
\hline Information on potential dangers and risks & 0.388 & 1.315 & 3.932 & 177 & 0.000 & 0.0803 \\
\hline Accommodation available near park & 0.601 & 2.097 & 3.824 & 177 & 0.000 & 0.0763 \\
\hline Sufficient, accessible, and clean toilets & 0.303 & 1.352 & 2.993 & 177 & 0.003 & 0.0481 \\
\hline Natural attractions well-conserved and mainta & 0.292 & 1.459 & 2.671 & 177 & 0.008 & 0.0387 \\
\hline Accessibility to sites well-maintained and adequate & 0.287 & 1.316 & 2.905 & 177 & 0.004 & 0.0325 \\
\hline Car parking adequate, safe, and secure & 0.157 & 1.197 & 1.753 & 177 & 0.081 & 0.0194 \\
\hline Pre-visit information helpful & 0.230 & 1.663 & 1.848 & 177 & 0.066 & 0.0189 \\
\hline Accessible shelter & 0.185 & 1.501 & 1.648 & 177 & 0.101 & 0.0151 \\
\hline Safe and secure environment within PCNP & 0.079 & 1.334 & 0.787 & 177 & 0.432 & 0.0035 \\
\hline
\end{tabular}


tion with the maintenance of tracks and paths, information on potential dangers and risks, and level of accommodation near PCNP. There is a small effect size between respondents' expectations and satisfaction with the car parking; the safe and secure environment at PCNP; previsit information; sufficient, clean, and accessible toilets; accessible shelter; accessibility to sites; and the conservation and maintenance of natural attractions.

\section{Considerations and Implications}

The following considerations and implications will further analyze the relationship between information sources and expectations, both matched and unmatched. Not only do the results create awareness of the varied information sources visitors' decisions are based on but also the results provide valuable insights into the role of the media in shaping expectations of protected areas. The implications from this study focus on the role of images in the previsit stage of the visitor experience, the link between induced images and expectations of the functional attributes at a destination, and the way protected-area management agencies should use this information to better cater for overall visitor satisfaction.

It is important to consider that this study did not fully identify the role of family and friends, especially their role as a solicited source, particularly as a functional or site-specific information provider. Accordingly, the data obtained on this medium may be slightly overemphasised. Consideration must also be given to the fact that this study was completed at PCNP, rather than a range of national parks. This research was completed during the off-season, or winter, which it is important to consider if the media or induced information sources present summer peak-season imagery. Although this is an important consideration, this summery imagery is more focused on the motivational or experiential attributes at the destination rather than the functional. It is also important to consider that this study did not identify the specific sources from which the expectations of visitors were formed, such as if the Web-based media were responsible for creating these unrealistic expectations of the facilities and services at the destination.
The implication for protected-area visitors from this research is that the functional attributes at a destination may be more points of dissatisfaction rather than satisfiers. Images have been emphasised as an important component of the visitor experience, shaping visitors' perceptions and expectations of a destination (Mannell \& Iso-Aloha, 1987). Formed during the previsit stage, these perceptions and expectations of an experience, created largely by the media, are either satisfied or not during a visitor's actual experience. Potentially, this can result in some visitors being satisfied with certain aspects of a destination, but left dissatisfied with others. A visitor may be satisfied with the level of privacy and solitude, the natural attractions, the flora and fauna at a park, yet dissatisfied with the information provided in the park. This would indicate the particular media used by this visitor contributed to the creation of realistic expectations of the experiential attributes, yet unrealistic expectations of the functional attributes at the setting. As a result, it is important not only that these functional attributes are up to a certain level at the destination but that the images conveyed to visitors of the facilities and services available are realistic, so visitors are not expecting a level of service the destination cannot provide.

With the familiarity role that induced media plays in shaping visitors' perceptions and expectations, the implication is that the induced media used by visitors created unrealistic expectations of many of the functional attributes at PCNP. In fact, visitors expected considerably more signage; access to facilities and infrastructure; information on the natural, cultural, and historical features; and considerably less traffic and crowding at sites than they experienced during actual visitation. Therefore, the induced media used by visitors to PCNP could be further utilized to shape and modify the expectations visitors have of these functional attributes. Consequently, situations where experiential satisfaction is high yet satisfaction with park management issues is low could be avoided.

The implication for Parks Victoria, as the managers of PCNP, is that careful consideration of the messages and images conveyed to visitors in induced media is necessary to cater to the overall satisfaction of visitors better. In the case of PCNP, these induced sources are providing visitors with 
expectations of the setting that are not met on-site, sometimes by a large margin. As most forms of induced media are directly controlled or influenced by parks management agencies, Parks Victoria should make a concerted effort to ensure the induced media supplied to visitors is carefully managed to create realistic functional and experiential expectations.

Parks management agencies can use the results of this study to ascertain valuable information on the role of the media in the previsit stage of a visitor experience. In particular, the implications of this research for parks management agencies focus on the role that induced media can play in creating expectations of the functional attributes at a destination. Parks management should realize that the media used by visitors not only creates experiential travel motivations but also expectations of the facilities and services at a destination, which are vital for overall satisfaction. It would be a shame to have a park that is aesthetically pleasing for visitors but fails in the provision of facilities and services due to unrealistic expectations created by induced forms of media. Therefore, as a means of enhancing visitor satisfaction, or at least mitigating dissatisfaction, parks management agencies should make a meticulous effort to ensure that the induced media available to visitors creates realistic expectations of not only the experiential aspects of the park but also the functional attributes of the destination. By further managing these induced images, protected-area management agencies can create realistic expectations of the experiential and functional attributes during the previsit stage, and ultimately better cater to the overall holistic process of visitor satisfaction.

This article also presents an implication for future research on media and the previsit experience in natural and protected areas. Munro et al. (2006) discuss the limited and seemingly token opportunities provided to stakeholders during the planning phase of the Port Campbell National Park Visitor Centre. Consequently, the visitor center was developed without much on-site interpretation or a full-time staff member. Future research needs to consider if the results obtained in this study reflect results from a national park or local council with a staffed visitor center.

\section{Conclusion}

In conclusion, researchers and protected-area management groups should use the results of this study to understand the importance of the media in creating expectations of a destination. This article particularly explores the role of induced media in creating expectations of the functional attributes at a destination. Fundamentally, the most important message conveyed in this research is that if there is an aesthetically pleasing national park, with the images conveyed of the park in the media representing this, with visitors expecting beauty and obtaining beauty, protected-area management agencies would be forgiven for expecting visitors to be totally satisfied with their experience. However, if the induced media used by visitors focuses completely on the experiential attributes at a destination and does not consider or manage visitors' expectations of the facilities and services at a park, then visitors may possess unrealistic expectations of these attributes at the setting. Essentially, this may result in visitors satisfied with their experience, although possessing a satisfaction gap with the services and facilities that accompany these experiences in the national park. So, although the experiential attributes are what motivates visitors to select a destination to visit, even if these experiential attributes are everything a visitor desires, poor performance due to inflated expectations of the functional attributes that accompany these experiential motivators may detract from the actual experience. This could result in a satisfaction gap, potentially with issues parks management agencies can control.

\section{References}

Akama, J. S., \& Kieti, D. M. (2003). Measuring tourist satisfaction with Kenya's wildlife safari: A case study of Tsavo West National Park. Tourism Management, 24(1), 73-81.

Baloglu, S., \& McCleary, K. W. (1999). A model of destination image formation. Annals of Tourism Research, 26(4), 868-897.

Beerli, A., \& Martin, J. D. (2004). Factors influencing destination image. Annals of Tourism Research, 31(3), 657-681.

Booth, K., \& Cullen, R. (1995). Recreation impacts. In P. A. Devlin, R. A. Corbett, \& C. J. Peebles (Eds.), Outdoor recreation in New Zealand: A review and syn- 
thesis of the research literature: Vol. 1 (pp. 99-136). Wellington, NZ: Department of Conservation.

Butler, R. W., \& Boyd, S. W. (2000). Tourism and national parks: Issues and implications. London: Wiley.

Burns, G. L., \& Howard, P. (2003). When wildlife tourism goes wrong: A case study of stakeholder and management issues regarding the dingoes on Fraser Island, Australia. Tourism Management, 24(6), 699-712.

Buultjens, J., Ratnayake, I., Gnanapala, A., \& Aslam, M. (2004). Tourism and its implications for management in Ruhuna National Park, Sri Lanka. Tourism Management, 25(2), 151-165.

Coffey, B. (2001). National park management and the commercialisation of nature: The Victorian experience. Australian Journal of Environmental Management, 8(2), $70-78$.

Cohen, J. (1969). Statistical power analysis for the behavioral sciences. New York: Academic Press.

Croy, W. G., \& Wheeler, F. (2007). Image formation: A research case. In C. M. Hall (Ed.), Introduction to Tourism: Dimensions and issues. Frenches Forest: Pearson Education.

Frawley, K. J. (1989). Cultural landscapes and national parks: Philosophical and planning issues. Australian Parks and Recreation, 25(3), 16-23.

Gartner, W. C. (1993). Image formation process. Journal of Travel and Tourism Marketing, 2(1), 191-215.

Gursoy, D., \& McCleary, K. W. (2004). An integrative model of tourists' information search behavior. Annals of Tourism Research, 31(2), 353-373.

Hammitt, W. E. (1980). Outdoor recreation: Is it a multiphase experience? Journal of Leisure Research, Second Quarter, 1980, 107-116.

Hwang, N. S., Lee, C., \& Chen, H. J. (2005). The relationship among tourists' involvement, place attachment and interpretation satisfaction in Taiwan's National Parks. Tourism Management, 26(2), 143-156.

Jenkins, O. H. (1999). Understanding and measuring tourist destination images. International Journal of Tourism Research, 1(1), 1-15.

Kearsley, G., \& Croy, W. G. (2001). A sustainable tourism programme: A review. Research Article Number One, Public Policy Research Institute, University of Otago, Dunedin, New Zealand.

Kerkvliet, J., \& Nowell, C. (2000). Tools for recreation management in parks: The case of the greater Yellowstone's blue-ribbon fishery. Ecological Economics, 34(1), 89-100.

Lange, E. (1990). Vista management in Acadia National Park. Landscape and Urban Planning, 19(3), 353-376.

MacKay, K. J., \& Fesenmaier, D. R. (2000). An exploration of cross-cultural destination image assessment. Journal of Travel Research, 38(May), 417-423.

Mannell, R. C., \& Iso-Aloha, S. E. (1987). Psychological nature of leisure and tourism experience. Annals of Tourism Research, 14(2), 314-331.
Mugica, M., \& De Lucio, J. (1996). The role of on-site experience on landscape preferences: A case study at Donana National Park, Spain. Environmental Management, 47(3), 229-239.

Munro, A., King, B., \& Polonsky, M. J. (2006). Stakeholder involvement in the public planning processThe case of the proposed Twelve Apostles Visitor Centre. Journal of Hospitality and Tourism Management, 13(1), 97-107.

Neal, J. D., Sirgy, J. M., \& Uysal, M. (1999). The role of satisfaction with leisure travel/ tourism services and experience in satisfaction with leisure life and overall life. Journal of Business Research, 44(2), 153-163.

Ostrowski, S. (1984). Tourism in protected areas: The case of Poland. Tourism Management, 5(2), 86-102.

Pallant, J. (2005). SPSS survival manual (2nd ed.). Sydney: Ligare.

Parks Victoria. (1998). Port Campbell National Park (electronic version). Retrieved September 13, 2006, from http://www.parkweb.vic.gov.au/resources/04_0213.pdf

Pigram, J. A., \& Jenkins, J. M. (1999). Outdoor recreation management. London: Routledge.

Pizam, A., \& Milman, A. (1993). Predicting satisfaction among first time visitors to a destination by using the expectancy disconfirmation theory. International Journal of Hospitality Management, 12(2), 197-209.

Smith, N., \& Croy, W. G. (2005). Presentation of dark tourism: Te Wairoa, the buried village. In C. Ryan, S. Page, \& M. Aicken (Eds.), Taking tourism to the limits: issues, concepts and managerial perspectives (pp. 199213). London: Elsevier.

Sternberg, E. (1997). The iconography of the tourism experience. Annals of Tourism Research, 24(4), 951-969.

Tourism Australia. (2006). 12 Apostles. Retrieved from http://www.australia.com/places_to_go/UW_Unique_ wonders/UW_12_Apostles/Reg_Exp_STD1.aust?L=en $\& \mathrm{C}=\mathrm{GB}$

Vaske, J. E., Donnelly, M. P., \& Whittaker, D. (2000). Tourism, national parks and impact management. In R. W. Butler \& S. W. Boyd (Eds.), Tourism and national parks: Issues and implications. Chichester: Wiley.

Vitterso, J., Vorkinn, M., Vistad, I. O., \& Vaagland, J. (2000). Tourist experiences and attractions. Annals of Tourism Research, 27(2), 432-450.

Walmsley, D. J., \& Jenkins, J. M. (1993). Appraisive images of tourist areas: Application of personal constructs. Australian Geographer, 24(2), 1-13.

Walmsley, D. J., \& Young, M. (1998). Evaluative images and tourism: The use of personal constructs to describe the structure of destination images. Journal of Travel Research, 36(Winter), 65-69.

Watkinson, R. (2002). Frogs or cassowaries: Cooperative marketing within the tourism industry. Journal of Ecotourism, 1(2/3), 181-189. 